\title{
From anticolonialism to postcolonialism: The emergence of Chinese indigenous psychology in Taiwan
}

\author{
Kwang-Kuo Hwang \\ National Taiwan University, Taipei, Taiwan
}

\begin{abstract}
$T$ his article gives a brief history of the emergence of Chinese indigenous psychology from the background of Westernized social psychology in Taiwan, and reviews the various debates that have surrounded the first decade of its progress from the perspectives of ontology, epistemology, and methodology. Careful analysis of these debates indicates that their themes are similar to dilemmas encountered by indigenous psychologists in other regions of the world. It is argued that breakthroughs need to be made on three levels for the development of indigenous psychology, namely, philosophical reflection, theoretical construction, and empirical research. There are three philosophical assumptions in cross-cultural psychology-absolutism, universalism, and relativismwhich correspond to three research orientations-imposed etic, derived etic, and emic. In order to achieve the goal of establishing a global psychology, then indigenous psychologists in non-Western societies must change their thinking from anticolonialism to postcolonialism; switch their philosophical assumption from relativism to universalism; assimilate the Western academic tradition; adopt a multiparadigm approach to construct formal theories on the functioning and mechanisms of the universal mind; use these to analyse the specific mentalities of a given culture; and use the results of this theoretical construction as a frame of reference for empirical research.
\end{abstract}

\begin{abstract}
et article présente un bref historique de l'émergence de la psychologie indigène chinoise, marquée par la psychologie sociale occidentale en Taiwan, ainsi qu'une revue des divers débats ayant entouré la première décennie de ses progrès tant sur les plans ontologique, épistémologique et méthodologique. Une analyse attentive de ces débats indique que leurs thèmes sont similaires aux dilemmes rencontrés par les psychologues indigènes dans les autres régions du monde. Une discussion porte sur la nécessité de considérer trois niveaux dans le développement de la psychologie indigène: soit les réflexions philosophiques, l'élaboration théorique et la recherche empirique. En raison de la présence de trois suppositions philosophiques dans la psychologie transculturelle, l'absolutisme, l'universalisme et le relativisme, lesquelles correspondent à trois orientations de recherche, étique (universelle) imposée, étique (universelle) dérivée et émique (particulière), afin d'arriver à établir une psychologie globale, les psychologues indigènes des sociétés non occidentales doivent changer leur pensée anti-colonialiste pour une pensée post-colonialiste; changer leur conception philosophique du relativisme vers l'universalisme; assimiler la tradition académique occidentale; adopter une approche multi-paradigme pour élaborer des théories formelles sur le fonctionnement et les mécanismes de la pensée universelle; utiliser ces théories pour analyser les mentalités spécifiques à une culture donnée; et utiliser les résultats de ces élaborations théoriques comme cadre de référence pour la recherche empirique.
\end{abstract}

$\bar{C}$ ste artículo proporciona una historia breve del surgimiento de la psicología autóctona china desde el marco de la psicología social occidentalizada en Taiwán, y reseña los diversos debates que han rodeado a la primera década de su progreso desde la perspectiva ontológica, epistemológica y metodológica. Un análisis cuidadoso de tales debates indica que sus temas son similares a los dilemas enfrentados por los psicólogos autóctonos en otras regiones del mundo. Se ha mantenido que los descubrimientos deben hacerse en tres niveles para desarrollar la psicología autóctona, es decir, la reflexión filosófica, la construcción teórica y la investigación empírica. Dado que existen 3 supuestos filosóficos en la psicología transcultural: absolutismo, universalismo, y relativismo, que corresponden a tres orientaciones en la investigación: etico impuesto, etico derivado y émico, para alcanzar la meta de establecer una psicología global, los psicólogos autóctonos en sociedades no occidentales deben cambiar su pensamiento del anti-colonialismo al post-colonialismo; modificar sus supuestos filosóficos del relativismo al universalismo; asimilar la tradición académica occidental; adoptar un enfoque

Correspondence should be addressed to Professor Kwang-Kuo Hwang, Dept. of Psychology, No. I, Section 4, Roosevelt Rd., Taipei 106, Taiwan (E-mail: kkhwang@ccms.ntu.edu.tw).

(C) 2005 International Union of Psychological Science

http://www.tandf.co.uk/journals/pp/00207594.html

DOI: $10.1080 / 00207590444000177$ 
multiparadigmático para construir teorías formales sobre el funcionamiento y los mecanismos de la mente universal; usar éstos para analizar las mentalidades especificas de una cultura determinada; y usar los resultados de esta construcción teórica como marco de referencia para la investigación empírica.

\section{INTRODUCTION}

The emergence of indigenous Chinese psychology can be regarded as the result of anticolonialism initiated by the scientific community of Taiwan. As the indigenous psychology took hold, a series of challenges and debates were encountered, similar to those within movements of indigenous psychology elsewhere. This article reviews the historical background to the emergence of indigenous social psychology in Taiwan and analyses the issues and debates that have occurred in order to realize the important insights they may bring.

\section{Dependent development of psychological research under academic colonialism}

The first psychology laboratory in Taiwan was established at Taipei Imperial University (now National Taiwan University, NTU) in 1928 by two Japanese professors, Linuma and Rikimaru. The psychological research was intended to study the folk psychology of aborigines to serve the expansionist government's policies when Japan was aggressively seeking to colonize its neighbours to the south (e.g., the Philippines). When Taiwan was restored to Nationalist China at the end of World War II, most Japanese returned to Japan, and in 1949 the first Department of Psychology was founded at NTU by a graduate of Beijing University, Hsiang-yu Su, who had a background in the field of philosophy.

After World War II, the Cold War made Taiwan dependent on the United States not only politically and economically, but also for science and technology. The Nationalist government held a chair in the United Nations under the title of the "Republic of China" and maintained an allied relationship with the US until the beginning of the 1970s, when it lost the seat to China. The history of close connection with the US has made Taiwan highly dependent on America for educational and academic resources: American textbooks or their translations were widely used, many teachers were educated in America, and many graduate students chose American institutions for advanced study. As a consequence, psychological research in Taiwan was Americanized. Many scholars sought research topics from "hot issues" in American journals, applied Western instruments and research methodologies to Taiwanese subjects, and attempted to interpret their findings in terms of popular American theories. Most research was published in local journals. Few individuals were able to publish articles in international academic journals with any frequency. Whether the contents were useful for the local society or whether there was a connection between the subject matter and the indigenous context were questions of secondary importance. Naive positivism, which assumed that there must be some truth in the advanced theories constructed by Western social scientists, was very popular in the scientific community of psychology in Taiwan.

\section{Emergence of indigenous Chinese psychology from "Americanized" social psychology}

For a long time, social scientists all over the world have been interested in studying Chinese personality and social behaviour. During the 1960s, various instruments for personality assessment including the CPI, MPI, and MMPI were translated into Chinese, a series of empirical studies was conducted, and abundant data were compiled to understand the structure of Chinese personality.

After Taiwan was expelled from the United Nations in 1971, Chiang Ching-kuo, who assumed the post of prime minister the following year, promoted the Ten Construction Projects, which provided infrastructure for rapid economic development. As a result of industrialization and urbanization, new social problems emerged and the demand for psychologists increased. Many universities began to provide programmes for training students of psychology. The population of the psychology community expanded, and the number of published articles accumulated rapidly.

Since 1970, social psychological research has expanded to include such topics as value change, individual modernity, stereotypes, social attitudes, attributional patterns, life stress, coping styles, interpersonal relationships, marriage and family problems, leadership and organizational behaviours, and criminal and deviant behaviours. Most research during this period was still a "transplant" of Western paradigms. With a 
community of only about 30 researchers, the themes of these studies were diverse and lacked focus.

In December 1981, Academia Sinica sponsored a conference on "Sinicization of Social and Behavioral Sciences." Several social scientists queried the adequacy of Western paradigms of research for Chinese society and criticized the popular style of mindless empirical research. Professor Kuo-shu Yang proposed the concept "Sinicization of Psychology," promoted it as an academic movement, and organized a Research Group of Indigenous Psychology with about 20 members. As a consequence of his active promotion, the group has accomplished a series of studies on such significant aspects of Chinese social behaviors as filial piety, yuan (interpersonal affinity), guanxi (relationships), mianzi (face), social-oriented achievement motivation, interpersonal conflict, leadership, and organizational culture. Some of their findings, along with empirical research findings in the field of social psychology, have been reviewed in K. S. Yang's 1999 article and incorporated into Michael Bond's (1986, 1996) two books on Chinese psychology.

\section{Reflections on the dependent development of academic research}

The 1981 conference was the turning point for the emergence of indigenous psychology from the "Americanized" social psychology in Taiwan. K. S. Yang was the key person who initiated this dramatic change. In the preface of the proceedings of the groundbreaking conference, K. S. Yang and Wen (1982) wrote:

\begin{abstract}
The subjects whom we studied are Chinese people in Chinese society, but, the theories and methods we used are mostly imported from the West or of the Western style. In our daily life, we are Chinese; when we are doing research, we become Western people. We repress our Chinese thoughts or philosophy intentionally or unintentionally, and make them unable to be expressed in our procedure of research.... Under such a situation, we can only follow the West step by step with an expectation to catch up their academic trend. ... Eventually, our existence in the world community of social and behavioral science becomes invisible at all. (p. ii)
\end{abstract}

In response to Yang's comments, the psychology community of Taiwan began to reflect on its own research. For example, Hwu (1985) reviewed articles published by members of the Chinese Psychiatric Association from 1948 to the 1980 s. He found that most were compilations of empirical data with little theoretical concern. "We can say that psychiatry in Taiwan is progressing without consistent core ideas. We just follow the trends of world psychiatry and are lacking the spirit of creation for ourselves" (p. 1).

Similar phenomena had been observed in the field of personality and social psychology. In the 1960 s, students in these fields translated a series of personality tests from the West to study values, interests, needs, and deviant behaviour of local people (Chuang, 1982; Hwang, 1982). Since the 1970 s, investigation had been expanded to cover achievement motivation, self-concept, attribution processes, and life stress, but research from this period was not free from academic dependency. For instance, C. F. Yang (1991) reviewed more than 60 research projects on self-concept by psychologists in Taiwan and Hong Kong for a period of 15 years, and concluded that most researchers habitually cited Western theories to support their research and adopted Western instruments of measurement. Most research used students, particularly junior high school students, as their subjects. The research designs were not guided by hypotheses derived from a particular theory, but concluded with post hoc interpretations of the empirical findings. Research of this type not only lacks theoretical meaning, but also has few connections to people in the local society. "As a result, we can say almost nothing about the Chinese concept of self with the research accomplished in the past 15 years" (C. F. Yang, 1991, p. 72).

Yu and Yang (1991) reviewed research on the achievement motive conducted in Taiwan over the past 35 years, and Chu (1996) reviewed 25 articles on personality and social psychology published in the Journal of Chinese Psychology from 1970 to 1980, with similar conclusions.

\section{The development of indigenous psychology and its related problems}

In the face of such problems, the tentative solution proposed by the Taiwanese community of psychology was an academic movement to promote indigenous research. Following the 1981 conference, a conference was held by the Department of Psychology, Hong Kong University at the end of 1988 entitled "Marching towards a New Era of Chinese Indigenous Psychology". Since the "Indigenization of Psychology" was the theme for discussion for the first time at this conference, an Interdisciplinary Symposium on Chinese 
Psychology and Behavior has been held every 2 years, and a large-scale International Council of Chinese Psychologists was held in November 1994. At each of those conferences, there have been papers discussing issues related to the indigenization of psychology, asking the scientific community to give up its comprador mentality of blindly following the Western research paradigm and, instead, to make a contribution to the progress of indigenous psychology (K. S. Yang \& Hwang, 1991; K. S. Yang \& Yu, 1993). A Laboratory of Research for Indigenous Psychology was established and the journal for Indigenous Psychological Research was inaugurated in 1993.

In order to promote an atmosphere of academic debate, which is essential for scientific progress but which is mostly absent in the Chinese cultural tradition, K. S. Yang designed a forum in the journal and invited several well-established scholars to comment on a target article. He proposed the concept of indigenous compatibility in the first issue of the journal, hoping to use it as a criterion for evaluating indigenous research (K. S. Yang, 1993). The adequacy of this concept was questioned by many scholars outside the camp of indigenous psychology. Four years later, K. S. Yang (1997b) published in the same journal another article entitled Indigenous compatibility of psychological research and its related issues. The second article gave rise to debate within the circle of indigenous psychology. The crucial issues in these debates were very similar. Considering these issues from a global perspective may help us to understand not only problems specific to the development of indigenous psychology in Taiwan, but also general issues that are common to indigenization movements worldwide.

\section{The appeals of anticolonialism}

According to K. S. Yang (1997a), basic motivations for promoting indigenous psychology were threefold: (1) scientific findings of psychological research often do not replicate in non-Western countries, whereas indigenous measures and studies may have better predictive validity than measures imported from the outside; (2) action oriented-the knowledge of indigenous psychology is urgently needed by practitioners to solve local problems, especially in developing countries; (3) nationalism or anticolonialism.

An historian, Fu (1995) identified the spirit of anticolonialism in the movement and pointed out that indigenization was a slogan popular in the Taiwanese academic community, not limited to psychology. Some opposed the West from the viewpoint of Chinese, others opposed China from the viewpoint of Taiwan; they were all in opposition to being colonized. For instance, K. S. Yang's (1993) article advocated that:

In order to popularize indigenous psychology effectively, indigenous psychologists should advise their colleagues earnestly and kindly, and let them know the necessity of indigenization in psychology; we should remind them the reason why Western psychologists emphasize that there is no hegemony and no national boundary in academic activities, because it is favorable for Western psychology to be accepted by non-Western psychologists, so their theories, thoughts, and methods can be easily exported to non-Western countries or societies. (p. 58)

$\mathrm{Fu}$ (1995) pointed out that this kind of argument is a direct accusation of anticolonialism. "If Western scholars read this paper, they may think that indigenous psychologists propose this kind of argument to avoid the challenge from the Western academic community." (p. 350), and "always neglect that there remains academic domination and hegemony in their own country" (p. 327).

K. S. Yang (1993) proposed 7 "Don'ts" and 10 "Dos" as guidance for developing indigenous psychology. Some of his "Dos" are as follows:

2. Be typically Chinese when functioning as a researcher and let Chinese ideas, values and ways of thinking be fully reflected in his or her research thinking process.

3. Take the psychological or behavioral phenomenon to be studied and its concrete, specific setting into careful consideration before assessing the possibility of adequately applying a Western concept, variable, theory, or method to Chinese subjects.

5. Give priority to the study of culturally unique psychological and behavioral phenomena or characteristics of the Chinese people.

8. Let research be based upon the Chinese intellectual tradition rather than the Western intellectual tradition. (p. 37)

Fu pointed out that, in the West, the academic centre is never fixed; it transfers from one place to another in history. The rise of a new academic centre is seldom achieved by calls for indigenization from native scholars who strongly advocate 
anti-colonialism, and bring such spiritual inspiration as 7 Don'ts, or 10 Dos. So far as the sinicization of research in social and behavioral science is concerned, "many of their problems cannot be solved by a spirit of anti-colonialism and independence" (Fu, 1995, pp. 349-350).

\section{Difficulties encountered by the indigenization movement of psychology}

What are the problems of the indigenization movement that cannot be resolved by the spiritual independence of anticolonialism? In responding to K. S. Yang's article (1993), Z. H. Lin (1995), who specializes in the philosophy of science, also questioned Yang's advocacy. Lin's opposition is related to the three questions of ontology, epistemology, and methodology encountered by the indigenization movement.

\section{Ontological problem}

According to K. S. Yang's (1993) original definition, indigenous compatibility means:

owing to the same cultural and biological influence, it tends to form a compatible state between the researcher's activity of research and knowledge system as well as local people's psychology and behaviors. This state of being tightly matched, tied, connected, or compatible, existing between local researcher's concepts as well as local people's psychology and behaviors. (p. 24).

Lin (1995, p. 327) disagreed with Yang. He asked, "Why is it more likely to obtain the truth by investigating the local phenomenon from the indigenous viewpoint?" Is it impossible for an outsider to study local people's psychology and behaviour? Why is their research on local people destined to be less "tightly matched, tied, connected, or compatible"? The question can be regarded as an ontological issue of indigenous psychology. The core of this issue is this: What is the object of study for indigenous research and who is capable of approaching or investigating the object appropriately? Answers to this question and their rationales are closely related not only to the methodology a researcher may adopt, but also to the nature of knowledge being sought.

\section{Methodological problem}

Based on the presupposition of ontology implied in his concept of "indigenous compatibility," K. S. Yang (1993) also proposed an argument about methodology for indigenous psychology. He cited the distinction made by the Filipino indigenous psychologist Enriquez (1989) between exogenous indigenization (indigenization from without) and endogenous indigenization (indigenization from within) and considered that psychology built through the approach of exogenous indigenization

adopts culture and history in other societies (usually the Western countries), but not their own as their origin of thinking. It is roughly a kind of deformed Western psychology, and fails to represent validly the characteristics and genuine phenomena of local society, culture and history. So I don't admit it as real indigenous psychology. What we mean by indigenous psychology is restricted to endogenous indigenous psychology, and that is what we seek. (K. S. Yang, 1993, p. 44)

Yang (1993) indicated that exogenous indigenous psychology fails to validly represent the characteristics and genuine phenomena of local society, culture, and history. Lin (1995, p. 328) argued that academic research needs a "neutral criterion," which is independent from all theories, to determine what are real characteristics and genuine phenomena. Otherwise, psychologists who follow various schools or adopt different theoretical framework may claim that their own theory represents the real characteristics and genuine phenomena. In that case, what should be the "neutral and independent criterion"?

\section{Epistemological problem}

Issues about "various schools or different theoretical framework" are related to what kind of knowledge is adopted by the researcher to interpret his objects, the role played by the researcher, and the goal of the research. These kinds of epistemological problems hidden in Yang's concept of indigenous compatibility had emerged in the controversy elicited by his 1993 article, in which he advised social scientists to "adopt more indigenous concepts," "to avoid adopting Western concepts habitually," and "to use folk terms and concepts as far as possible in order to maintain original facts of the phenomena to be studied"' (K. S. Yang, 1993, p. 37).

Lin (1995, p. 328) pointed out that Yang didn't indicate clearly if the researcher should adopt indigenous concepts as far as possible only when he is describing the phenomena or even when he is interpreting the data. If it is the latter case, indigenous psychological theories will use a great 
many indigenous concepts. These concepts could be understood correctly only by the specialists who are very familiar with indigenous society, culture, and history. In this case, "how can indigenous psychologists from different areas of the world communicate with each other?" "How can we build global psychology or human psychology on the basis of regional indigenous psychologies?"

Lin's query (1995) is related to two questions. First, should psychologists make "the second degree of interpretation" or "maintain original facts of the phenomena"? Second, on the basis of findings of indigenous psychology, how can we develop global or human psychology that represents not only human universality, but also indigenous specificity?

\section{The "philosophical switch" in the indigenization movement of psychology}

Viewed from a global perspective, it is not difficult to see that the controversies caused by $\mathrm{K}$. S. Yang's 1993 article resemble those faced by other non-Western psychologists who have been trying to develop indigenous psychology in their own societies (Enriquez, 1982; Sinha, 1997). Most indigenous psychologists believe that indigenous psychology is "the study of human behavior and mental processes within a cultural context that relies on values, concepts, belief systems, methodologies, and other resources indigenous to the specific ethnic or cultural group under investigation" (Ho, 1998, p. 94). Through "the scientific study of human behavior that is native, that is not transported from other regions, and that is designed for its people" (Kim \& Berry, 1993, p. 2), they are able to obtain "a psychological and practical system based on and responsive to indigenous culture and indigenous realities" (Enriquez, 1993, p. 158). They advocated "a bottom-up model-building paradigm" (Kim, 2000 , p. 265) to study people as "the interactive and proactive agents of their own actions" that occur in a meaningful context (Kim, Park, \& Park, 2000 , p. 71), in an expectation to develop a psychology whose "concepts, problems, hypothesis, methods, and test emanate from, adequately represent, and reflect upon the cultural context in which the behavior is observed" (Adair, Puhan \& Vohra, 1993, p. 149).

Such advocacy for the indigenization of psychology is similar to that proposed by K. S. Yang (1993) in Taiwan. But it was criticized by mainstream psychologists who argued that the advantages of an indigenous approach are also claimed by anthropologists. Accumulating anthropological data with this approach may not have direct implication for the progress of scientific psychology (Triandis, 2000). If the difference in behavioural repertoires across cultural populations implies that we need an indigenous psychology, how many indigenous psychologies will we have (Poortinga, 1999)?

Of course, most indigenous psychologists are fully aware of the difficulties that might be encountered by their indigenous approach. For example, Ho (1988, p. 68) who is advocating an Asian psychology, has warned indigenous psychologists that, "if we regard the psychology developed by Western or American psychologists as a product of ethnocentrism, could we say the same thing to products of indigenous approach? Is it a kind of double standard?"

In order to meet the challenge, most indigenous psychologists have argued that the development of numerous indigenous psychologies is not their final goal. Rather, their final goal is to develop an Asian psychology (Ho, 1988), a global psychology (Enriquez, 1993), or a universal psychology (Berry \& Kim, 1993; Kim \& Berry, 1993; Sinha, 1997). Even K. S. Yang (1993) also advocated that the final goal of developing indigenous psychologies is to establish "a human psychology" or "a global psychology." In order to achieve this goal of universalism, they have proposed several research methods or approaches, including the derived etic approach (Berry, 1989; Berry \& Kim, 1993), the emic-etic-theorics threefold distinction method (Ho, 1988), and the "cross indigenous method" of using the approach of "indigenization from within" and "indigenization from without" interchangeably (Enriquez, 1989). Even K. S. Yang (1997b, 1997c) proposed a cross-cultural indigenous psychology approach and advocated it as a road to "a global psychology."

It seems that the transition from indigenous psychologies to an Asian psychology, global psychology, universal psychology, or a human psychology implies a significant change in philosophical assumption. Indigenous psychologists will not achieve success until they take into consideration not only the methods they use, but also their beliefs about ontology, epistemology, and methodology. This point can be illustrated by an important argument proposed by Berry, Poortinga, Segall, and Dasen (1992). They pointed out that there are three philosophical assumptions in cross-cultural psychology: absolutism, universalism, and relativism, which correspond to three research orientations: imposed etic, derived etic, and emic. Westernized (or Americanized) 
psychologists, who are strongly opposed by indigenous psychologists, ignore cultural differences and insist on the imposed etic approach as well as its philosophical assumption of absolutism by imposing Western theories and research instruments on people of non-Western societies (Berry, 1989). In contrast, indigenous psychology researchers follow the strategy of the emic approach, with its philosophical assumption of relativism, using indigenous instruments and methods of research with the expectation of developing substantial theories or models that are culturally specific to local people. However, when indigenous psychologists change their ultimate goal to develop a global psychology, universal psychology, or human psychology, their philosophical assumption has been shifted from relativism to universalism. They are supposed to seek entirely different knowledge through an entirely different method.

\section{The development of universal psychology}

This point can be illustrated by the distinction between mind and mentality as proposed by cultural psychologist Shweder (2000) and his colleagues (Shweder, Goodnow, Hatano, LeVine, Markus, \& Miller, 1998). Mind means "totality of actual and potential conceptual contents of human cognitive process" (Shweder, 2000, p. 210), while mentality means any "cognized and activated subset of mind" that has been held by a particular person or human being. Mentality can be an object for cultural psychologist to study; but mind should contain all possible conceptual contents that any human being might ever cognize, activate, or represent. To achieve the goal of developing global psychology by an inductive approach of positivism, it would take a very large-scale research programme to travel across the whole world to investigate all indigenous psychologies, and take into account the history and even the future of each culture. How can such a dilemma be avoided?

The development of universal psychology should be understood as an academic mission for indigenous psychologists to construct not only substantial theories that can be used to explain psychology or behaviour in a particular society, but also formal theories that are supposed to be applicable to various cultures.

This goal cannot be attained by any inductive method of positivism, but it can be attained by a multiparadigm approach of post-positivism. In order to construct this kind of knowledge, indigenous psychologists in non-Western societies should abandon the inductive approach of positivism, and adopt a totally different ontology/epistemology/ methodology. Their thinking should change from anticolonialism to postcolonialism. They cannot restrict their research interests to the scope of their own culture. They should be able to assimilate the related academic achievements accumulated by Western civilization and utilize them as resources for their own research. As Chinese indigenous psychology has progressed, this point has emerged from debate on K. S. Yang's (1997b) elaboration of his concept of "indigenous compatibility."

\section{ONTOLOGICAL ISSUES: PHILOSOPHICAL SWITCH}

Four years after the publication of K. S. Yang's 1993 article, he published another target article in Indigenous Psychological Research and invited comments from several scholars who had been engaged in or had paid close attention to the progress of indigenous psychology over a long period of time. Analysing the contents of their debate enables us to see what is meant by "philosophical switch" in the development of indigenous psychology.

Hence K. S. Yang's (1993) emphasis on locality in defining the concept of indigenous compatibility had been challenged, he agreed that "in some specific conditions, foreign scholars can also do indigenous research" and revised his definition as follows:

The investigators' research activities (including topic selection, conceptual analysis, research design, and theory construction) must be sufficiently congruous with, compatible to, or in harmony with the native people's studied psychological or behavioral elements, structures, mechanisms, or processes as rooted in their ecological, economic, social, cultural, or historical contexts. (K. S. Yang, 1997b, p. 87)

K. S. Yang (1997b) differentiated two kinds of indigenous compatibility: focal indigenous compatibility "stresses the congruity of the researcher's theory, methods, and results with the studies of psychological or behavioral phenomenon itself, without taking its context into direct consideration"; while contextual indigenous compatibility "places emphasis on the congruity of the theory, methods, and results with the studied phenomenon-in-context as a whole, rather than with the phenomenon in isolation from its context" (see also K. S. Yang, 2000, p. 250).

However, referring to the conceptual framework proposed by Berry et al. (1992), the crucial 
question is: Can indigenous psychologists insist on the philosophical presumption of relativism and strive to develop psychological knowledge that can describe the "real characteristics and genuine appearance" of local society? Or, do they need to shift their philosophical presupposition to universalism in order to develop a formal theory or model that is supposed to depict both human university and local specificity?

If an indigenous psychologist insists on the philosophy of relativism, she or he may follow the inductive methodology of positivism. Nevertheless, if they want to develop global psychology or universal psychology, they has to shift their philosophical presumption to universalism, to reflect the role a researcher plays in the academic activities, and to adopt a multiparadigm approach of postpositivism to do creative work in academic investigation.

\section{EPISTEMOLOGICAL ISSUE: FIRST-DEGREE OF INTERPRETATION OR SECOND-DEGREE OF INTERPRETATION}

The debates elicited by K. S. Yang's (1997b) article had been processed along these two themes. In their comments on Yang's arguments about "indigenous compatibility," both Hwang (1997) and Yeh (1997) cited Schutz's (1962) differentiation between "first-degree of interpretation" and "second-degree of interpretation," and pointed out that Yang's definition has an implication that a researcher's interpretation should be kept as close to the subject's first-degree of interpretation as possible. This is not the purpose of academic research.

Hwang (1993) argued that "knowledge" and "experience" are completely different. The living experience of human beings is basically in a state of chaos. When a researcher attempts to construct a substantial theory on the basis of his subject's experience, he should transform the subject's experience into knowledge through "rational reconstruction" but not "rational representation." He can represent neither his own experience, nor his subject's experience. Putting in Geertz's (1973) terminology, a researcher should make "thick description" with a reference to the subject's "thin description" of his own experience, but not represent the subject's statement as it is.

\section{Interpretation of culture}

Yeh (1997, p. 127) pointed out that the researcher's second-degree of interpretation about the actor's subjective meaning is neither the restoration of the actor's conscious interpretation (i.e., the firstdegree of interpretation) originating from his personal interest in his daily life, nor the interpretation in accordance with the theory that is familiar to, preferred by, or identified with the researcher. A researcher should not reduce his interpretation of the phenomena to the subject's recognization, interpretation, or feeling of one's own experience without any reservation or modification. What we expect a researcher to provide us with is a systematic knowledge that must be more than, and different from, the common sense of ordinary people (Yeh, 1997, p. 126).

Therefore, the crucial aspect is: "how a researcher can manage the subject's psychology and behavior adequately so as to present their cultural and social meanings in an illuminative way" (Yeh, 1997, p. 127).

\section{Construction of theory}

Yeh proposed his arguments from the perspective of hermeneutics. Hwang (1993) indicated that, since the mainstream of positivism has been replaced by postpositivism (Achinstein \& Baken, 1969), the scientist's major task is not to describe his external world "as it is" or "compatibly" by the inductive approach, but to construct tentative theory to solve various problems encountered in his research. He cited main ideas of evolutionary epistemology (Popper, 1963) and argued that the process of scientific research should begin with "problem." When a psychologist finds that the empirical data cannot be explained by theories imported from the West, a tentative theory should be proposed to solve the problem, examine the theoretical proposition with empirical data, and eliminate errors in the conjecture. A scientist cannot "verify" any theoretical proposition. Instead scientists try to "falsify" it, and just retain it temporarily before it is falsified.

From Popper's perspective, theory is not induced from empirical facts, it is constructed by a scientist with critical rationality. A scientist may derive a hypothesis and test it empirically, but a theory is not supposed to describe the reality "compatibly." Hwang (1997) quoted a famous saying of Popper's to explain his viewpoint: "Our intellect does not draw its laws from nature, but tries-with varying degrees of success-to impose upon nature laws which it freely invents" (Popper, 1963, p. 191).

Logical empiricist Hempel also argued that the transition from data to theory requires creative 
imagination. "Scientific hypotheses and theories are not derived from observed facts, but invented in order to account for them. They constitute guesses at the connections that might obtain between the phenomena under study, at uniformities and patterns that might underlie their occurrence." (Hempel, 1966, p. 15)

\section{THE METHODOLOGICAL ISSUE: CRITERION OF ACADEMIC RESEARCH}

Hwang (1997, p. 169) indicated clearly that the current mainstream psychology is a product of a unique way of thinking, which has emerged from Western civilization since the Renaissance. Contemporary psychologists are urged to adopt Western paradigms for research and to evaluate their research products with rigorous academic criteria. He argued that indigenous compatibility can be regarded as a guiding principle for the indigenization movement of psychology, but it cannot be used as an academic standard for evaluating the quality of research. "I wonder if Prof. Yang will agree with my argument or not?" (Hwang, 1997, p. 169).

In K. S. Yang's (1997c, p. 198) response, he admitted that his discourse about what is "matched, fitted, and compatible" is undeniably ambiguous. He argued that parts of what he means by "matched, fitted, or compatible" could be interpreted further by Yeh's statement. However, Yang opposed Hwang's suggestion, stating:

There are many standards for evaluating the quality of research. What has been mentioned frequently in textbooks about methodology or research methods includes, at least, the (theoretical and practical) importance of research topic, the adequacy of conceptualizing the phenomena, the reasonableness of research design (in terms of subjects, methods, and instruments), the (theoretical and practical) importance of research findings, the illumination from discussing the research findings, and the achievement of theoretical development. Those are common standards for evaluating the quality of research. In order to promote the idea of indigenous psychology, indigenous compatibility must be added to these standards so as to transform the Westernized research, which might be evaluated as "good" or "fair" by those standards, into a real indigenous one. (K. S. Yang, 1997c, p. 211)

K. S. Yang (1997c) emphasized that he has differentiated indigenous psychology into "monocultural indigenous psychology" and "cross-cultural indigenous psychology." $\mathrm{He}$ believes that Westernized or Americanized psychology is also a "monocultural indigenous psychology". Constructing theories of regional psychology can rely not only on monocultural indigenous research, but also on cross-cultural indigenous research, as well as the integration of knowledge from several related indigenous psychologies. Four years later, he also proposed four methods of integration in cross-cultural indigenous psychology, namely, empirical integration, theoretical integration, assimilative synthesis, and accommodative synthesis (K. S. Yang, 2000).

\section{Conclusion}

The cross-cultural indigenous psychology as advocated by $\mathrm{K}$. S. Yang is basically an inductive approach of positivism. The feasibility of his integrative method is an open-ended question waiting for demonstration. Nevertheless, his belief that the final goal of indigenous psychologies is to establish a "human psychology" or "global psychology" may urge him and other indigenous psychologists to seek a solution to this problem and make the philosophical switch from relativism to universalism. During this process, it is inevitable for them to encounter the dilemma mentioned earlier in this article. In order to escape the dilemma, they have to seek a new philosophy for the basis of developing indigenous psychology. This philosophy should be able to explain not only the essential features of modernity, but also the historical situation of non-Western societies. Most important of all, it should be able to explain why and how these societies have to develop indigenous psychology (or indigenous social science) during the process of globalization.

There are three levels of breakthrough to be made for a real progression of indigenous psychology, namely: philosophical reflection, theoretical construction, and empirical investigation. Indigenous psychologists must understand that modernization is an inevitable trend of human civilization. They have to abandon the mentality of anticolonialism, and move forward into the stage of postcolonialism. They should assimilate the accumulated achievement of Western civilization with an open mind. By doing so, they may understand that if the philosophy of science switches from positivism to postpositivism, their chief mission is neither to develop an indigenous psychology of relativism, nor to establish a global psychology or human psychology of universalism, but to construct formal theories that are supposed 
to be applicable to various cultures on the one hand, and can be used to explain the specific features of indigenous culture on the other, then to take these theories as a frame of reference for conducting empirical research in a given society.

It seems to me that constructive realism advocated by the Vienna School in recent years is a philosophy of science that can fulfil the requirements stated above (Slunecko, 1997; Wallner, 1994). In an article entitled Constructive realism and Confucian relationalism, I interpreted how to develop models of indigenous psychology on the basis of constructive realism (Hwang, 2001a). In Chinese relationalism: Theoretical construction and methodological considerations and other related writings (Hwang, 1997-8, 2000, $2001 \mathrm{a}, 2001 \mathrm{~b}$ ), I have explained further how to construct theoretical models that meet the aforementioned conditions, and how to use them to do the work of cultural analyses. It is expected that a new way for indigenous psychological research can be opened up through such an approach.

\section{REFERENCES}

Achinstein, P., \& Baker, S. F. (1969). The legacy of logical positivism: Studies in the philosophy of science. Baltimore: John Hopkins Press.

Adair, J. G., Puhan, B. N., \& Vohra, N. (1993). Indigenous psychology: Empirical assessment of progress in Indian research. International Journal of Psychology, 28, 149-169.

Berry, J. W. (1989). Imposed etics-emics-derived etics: The operationalization of a compelling idea. International Journal of Psychology, 24, 721-735.

Berry, J. W., \& Kim, U. (1993). The way ahead: From indigenous psychologies to a universal psychology. In U. Kim \& J. W. Berry (Eds.), Indigenous psychologies: Research and experience in cultural context (pp. 277-280). Newbury Park, CA: Sage.

Berry, J. W., Poortinga, Y. H., Segall, M. H., \& Dasen, P. R. (1992). Cross-cultural psychology: Research and applications. New York: Cambridge University Press.

Bond, M. H. (1986). The psychology of the Chinese people. Hong Kong/New York: Oxford University Press.

Bond, M. H. (1996). The handbook of Chinese psychology. Hong Kong/New York: Oxford University Press.

Chu, R. L. (1996). An investigation on family education and parent-child relationship. Paper presented at the Symposium on Family Psychology: Couple and generational interactions [in Chinese]. Taipei: Institute of Ethnology, Academia Sinica.

Chuang, Y. J. (1982). The development of psychological measurements in Taiwan [in Chinese]. Taiwan: Chinese Society of Behavioral Science.

Enriquez, V. G. (1982). Towards a Filipino psychology. Quezon City, the Philippines: Psychology Research and Training House.
Enriquez, V. G. (1989). Indigenous psychology and national consciousness. Tokyo: Institute for the Study of Languages and Cultures of Asia and Africa.

Enriquez, V. G. (1993). Developing a Filipino psychology. In U. Kim \& J. Berry (Eds.), Indigenous psychologies: Research and experience in cultural context (pp. 152-169). Newbury Park, CA: Sage.

$\mathrm{Fu}$, D. W. (1995). Indigenous psychology and anticolonialism [in Chinese]. Indigenous Psychological Research in Chinese Societies, 4, 348-352.

Geertz, C. (1973). The interpretation of cultures. New York: Basic Books.

Hempel, C. G. (1966). Philosophy of natural science. Englewood Cliffs, NJ: Prentice Hall.

Ho, D. Y. F. (1988). Asian psychology: A dialogue on indigenization and beyond. In A. C. Paranjpe, D. Y. F. Ho \& R. W. Rieber (Eds.), Asian contributions to psychology (pp. 53-77). New York: Praeger.

Ho, D. Y. F. (1998). Indigenous psychologies: Asian perspectives. Journal of Cross-cultural Psychology, 29, 88-103.

Hwang, J. H. (1982). Comments on recent research in psychology of Chinese personality [in Chinese]. Academic Journal of Educational Psychology and Counseling, National Taiwan Normal University, 15, 227-241.

Hwang, K. K. (1993). Comments on ways of deepening indigenous psychological research [in Chinese]. Indigenous Psychological Research in Chinese Societies, 1, 193-200.

Hwang, K. K. (1997). Indigenous compatibility: Orientation of academic movement or criterion for evaluating academic research [in Chinese]. Indigenous Psychological Research in Chinese Societies, 8, 159-171.

Hwang, K. K. (1997-8). Guanxi and Mientze: Conflict resolution in Chinese society. Intercultural Communication Studies, 7, 17-37.

Hwang, K. K. (2000). Chinese relationalism: Theoretical construction and methodological considerations. Journal for the Theory of Social Behavior, 30, 155-178.

Hwang, K. K. (2001a). Constructive realism and Confucian relationalism: Philosophical foundation and theoretical construction for the development of indigenous psychology. Paper presented at International Workshop on Scientific Advances in Indigenous Psychologies: Philosophical, Cultural, and Empirical Contributions. Taipei: Institute of Ethnology, Academia Sinica, \& Office of Research in Chinese Indigenous Psychology, NTU.

Hwang, K. K. (2001b). The deep structure of confucianism: A social psychological approach. Asian Philosophy, 11, 179-204.

Hwu, H. K. (1985). Conceptual model of psychiatry. Chinese Journal of Mental Health, 2, 1-17.

Kim, U. (2000). Indigenous, cultural, and cross-cultural psychology: A theoretical, conceptual, and epistemological analysis. Asian Journal of Social Psychology, 3, 265-287.

Kim, U., \& Berry, J. W. (1993). Introduction. In U. Kim \& Berry (Eds.), Indigenous psychologies: Research and experience in cultural context (pp. 1-29). Newbury Park, CA: Sage.

Kim, U., Park, Y.-S., \& Park, D. (2000). The challenge of cross-cultural psychology: The role of the 
indigenous psychologies. Journal of Cross-Culture Psychology, 31, 63-75.

Lin, Z. H. (1995). Some preliminary comments on Prof. K. S. Yang's article "Why do we need to develop an indigenous Chinese psychology?" [in Chinese]. Indigenous Psychological Research in Chinese Societies, 4, 324-328

Poortinga, Y. H. (1999). Do differences in behavior imply a need for different psychologies? Applied Psychology: An International Review, 46, 419-432.

Popper, K. K. (1963). Conjectures and refutations: The growth of scientific knowledge. New York: Harper \& Row.

Schutz, A. (1962). Collected papers I: The problem of social reality. The Hague: Martinus Nijhoff.

Shweder, R. A. (2000). The psychology of practice and the practice of the three psychologies. Asian Journal of Social Psychology, 3, 207-222.

Shweder, R. A., Goodnow, J., Hatano, G., LeVine, R., Markus, H., \& Miller, P. (1998). The cultural psychology of development: One mind, many mentalities. In W. Damon (Ed.), Handbook of child psychology, Vol. 1 (pp. 865-937). New York: John Wiley.

Sinha, D. (1997). Indigenous psychology. In J. W. Berry, Y. Poortinga, \& J. Pandey (Eds.), Handbook of crosscultural psychology: Vol. 1. Theory and method (2nd ed., pp. 124-169). Boston, MA: Allyn \& Bacon.

Slunecko, T. (Ed.). (1997). The movement of Constructive Realism. Wien: Wilhelm Braumüller.

Triandis, H. C. (2000). Dialectics between cultural and cross-cultural psychology. Asian Journal of Social Psychology, 3, 185-195.

Wallner, F. (1994). Constructive Realism: Aspects of new epistemological movement. Wien: W. Braumüller.

Yang, C. F. (1991). A review on studies of self in Hong Kong and Taiwan. In C. F. Yang \& H. R. Kao (Eds.), Chinese people and Chinese mind: Personality and society [in Chinese] (pp. 15-92). Taipei: YuanLiou Publishing.

Yang, K. S. (1993). Why do we need to develop an indigenous Chinese psychology? [in Chinese].
Indigenous Psychological Research in Chinese Societies, 1, 6-88.

Yang, K. S. (1997a). Indigenous westernized Chinese psychology. In M. H. Bond (Ed.), Working at the interface of cultures: Eighteen lives in social science (pp. 62-76). London: Routledge.

Yang, K. S. (1997b). Indigenous compatibility in psychological research and its related problems. Indigenous Psychological Research in Chinese Societies [in Chinese]. 8, 75-120.

Yang, K. S. (1997c). The third discussion on indigenous compatibility: A further clarification. In K. S. Yang (Ed.), Indigenous psychological research in Chinese societies [in Chinese], 8, 197-237.

Yang, K. S. (1999). Towards an indigenous Chinese psychology: A selective review of methodological, theoretical, and empirical accomplishments. Chinese Journal of Psychology, 41, 181-211.

Yang, K. S. (2000). Monocultural and cross-cultural indigenous approaches: The royal road to the development of a balanced global psychology. Asian Journal of Social Psychology, 3, 241-263.

Yang, K. S., \& Hwang, K. K. (Eds.). (1991). Chinese psychology and behaviors [in Chinese]. Taipei: Laureate Publishing.

Yang, K. S., \& Wen, C. I. (Eds.). (1982). Preface. In K. S. Yang \& C. I. Wen (Eds.), The sinicization of social and behavioral science research in China in Chinese] (pp.i-vii). Taipei: Institute of Ethnology, Academia Sinica.

Yang, K. S., \& Yu, A. B. (Eds.). (1993). Chinese psychology and behaviors: Beliefs and methods [in Chinese]. Taipei: Laureate Publishing.

Yeh, C. Z. (1997). An alternative thinking on indigenous compatibility [in Chinese]. Indigenous psychological research in Chinese societies, 8, 121-139.

$\mathrm{Yu}$, A. B., \& Yang, K. S. (1991). A reflection on the indigenization of achievement motive. In C. F. Yang \& H. R. Kao (Eds.), Chinese people and Chinese mind: Personality and society [in Chinese] (pp. 201-290). Taipei: Yuan-Liou Publishing. 
Copyright of International Journal of Psychology is the property of International Union of Psychological Science. The copyright in an individual article may be maintained by the author in certain cases. Content may not be copied or emailed to multiple sites or posted to a listserv without the copyright holder's express written permission. However, users may print, download, or email articles for individual use. 